\title{
Furniture wood waste as a potential renewable energy source
}

\section{A thermogravimetric and kinetic analysis}

\author{
Agnieszka Plis $^{1} \cdot$ Michalina Kotyczka-Morańska $^{1} \cdot$ Marcin Kopczyński $^{1}$ • \\ Grzegorz Labojko ${ }^{1}$
}

Received: 12 October 2015 / Accepted: 6 June 2016/Published online: 20 June 2016

(c) The Author(s) 2016. This article is published with open access at Springerlink.com

\begin{abstract}
In this study, the combustion behavior of raw waste wood from furniture and samples torrefied at temperatures of $473,513,553$ and $593 \mathrm{~K}$ was investigated. TG-DTG analysis showed that the mass loss in the first stage of the process decreased with the temperature of torrefaction, whereas the temperature in the second stage increased. The influence of torrefaction and combustion parameters on greenhouse gas emissions were investigated by the FTIR technique. The characteristic combustion parameters were also determined. The ignition temperatures for the furniture wood waste and samples torrefied at 473,513 and $553 \mathrm{~K}$ from 549 to $559 \mathrm{~K}$, whereas that of the sample torrefied at $593 \mathrm{~K}$ was significantly higher $(600 \mathrm{~K})$. All samples were completely burnt at 813-843 K, after 29-35 min, depending on the torrefaction temperature. Kinetic parameters are determined using a two-step firstorder reaction. The activation energy value for the first stage increased with the increasing temperature of torrefaction, from 68 to $125 \mathrm{~kJ} \mathrm{~mol}^{-1}$, whereas the temperature in the second stage decreased from 108 to $47 \mathrm{~kJ} \mathrm{~mol}^{-1}$. A similar correlation was observed for the pre-exponential value $A$. In the case of the torrefied furniture wood waste at $593 \mathrm{~K}$, the combustion process runs as a single first-order reaction. The calculated data were fitted to the experimental data very accurately $\left(R^{2}>0.9992\right.$ and standard deviation $\left.<6.7 \%\right)$, and the kinetic model was correctly founded. The linear relationship between $\log A$ and $E_{\mathrm{a}}$ provides a way to predict the kinetic parameters of the combustion process.
\end{abstract}

Agnieszka Plis

aplis@ichpw.pl

1 Institute for Chemical Processing of Coal, Zamkowa Street 1, 41-803 Zabrze, Poland
Keywords Furniture wood waste - Torrefaction · TG · FTIR · Consecutive first-order reactions

\begin{tabular}{|c|c|}
\hline \multicolumn{2}{|c|}{ Abbreviations } \\
\hline FW & Furniture waste wood \\
\hline TFW & Torrefied furniture waste wood \\
\hline$f(\alpha)$ & Hypothetical model of the reaction mechanism \\
\hline$g(\alpha)$ & Integral function of conversion \\
\hline$k$ & Reaction rate \\
\hline$A$ & Pre-exponential factor $\left(\min ^{-1}\right)$ \\
\hline$E_{\mathrm{a}}$ & Activation energy $\left(\mathrm{kJ} \mathrm{mol}^{-1}\right)$ \\
\hline$T$ & Absolute temperature (K) \\
\hline$t$ & Time $(\min )$ \\
\hline$R$ & Universal gas constant $\left[8.314\left(\mathrm{~J} \mathrm{~K}^{-1} \mathrm{~mol}^{-1}\right)\right]$ \\
\hline$\alpha$ & Conversion degree \\
\hline$m_{0}$ & Starting mass of the sample (mg) \\
\hline$m_{\mathrm{t}}$ & Mass of the sample at time $t(\mathrm{mg})$ \\
\hline$m_{\mathrm{ash}}$ & Final mass of the sample (mg) \\
\hline$\beta$ & Heating rate $\left(\mathrm{K} \mathrm{min}^{-1}\right)$ \\
\hline$\overline{\mathrm{TG}_{\exp _{\mathrm{j}}}}$ & Average value of experimental mass loss $(\%)$ \\
\hline$\overline{E_{\mathrm{a}}}$ & $\begin{array}{l}\text { Average value of activation energy from values } \\
\text { obtained for four heating rates }\left(\mathrm{kJ} \mathrm{mol}^{-1}\right)\end{array}$ \\
\hline $\bar{A}$ & $\begin{array}{l}\text { Average value of pre-exponential factor from } \\
\text { values obtained for four heating rates }\left(\mathrm{min}^{-1}\right)\end{array}$ \\
\hline$S$ & $\begin{array}{l}\text { Standard deviation of kinetic parameters from } \\
\text { values obtained for four heating rates }\end{array}$ \\
\hline$t_{(\mathrm{n}, 1-0.5 \alpha)}$ & $\begin{array}{l}\text { Value of Student's } t \text { test for } n \text { measurement } \\
\text { points under the consideration of a two-sided } \\
\text { confidence level }(0.95)\end{array}$ \\
\hline$n$ & Number of experimental data \\
\hline$p$ & Number of parameters $(p=2)$ \\
\hline $\mathrm{HHV}$ & Higher heating value $\left(\mathrm{J} \mathrm{g}^{-1}\right)$ \\
\hline $\mathrm{V}_{\mathrm{m}}$ & Volatile matter content $(\%)$ \\
\hline $\mathrm{C}$ & Carbon content $(\%)$ \\
\hline
\end{tabular}

Abbreviations

woo

$f(\alpha) \quad$ Hypothetical model of the reaction mechanism

$g(\alpha) \quad$ Integral function of conversion

$k \quad$ Reaction rate

$A \quad$ Pre-exponential factor $\left(\mathrm{min}^{-1}\right)$

$E_{\mathrm{a}} \quad$ Activation energy $\left(\mathrm{kJ} \mathrm{mol}^{-1}\right)$

$T \quad$ Absolute temperature (K)

$t \quad$ Time (min)

$R \quad$ Universal gas constant $\left[8.314\left(\mathrm{~J} \mathrm{~K}^{-1} \mathrm{~mol}^{-1}\right)\right]$

$\alpha \quad$ Conversion degree

$m_{0} \quad$ Starting mass of the sample $(\mathrm{mg})$

$m_{\mathrm{t}} \quad$ Mass of the sample at time $t(\mathrm{mg})$

$m_{\text {ash }} \quad$ Final mass of the sample $(\mathrm{mg})$

$\beta \quad$ Heating rate $\left(\mathrm{K} \mathrm{min}^{-1}\right)$
$\mathrm{TG}_{\mathrm{exp}}$ Average value of experimental mass loss (\%)

Average value of activation energy from values obtained for four heating rates $\left(\mathrm{kJ} \mathrm{mol}^{-1}\right)$ values obtained for four heating rates $\left(\mathrm{min}^{-1}\right)$ values obtained for four heating rates points under the consideration of a two-sided confidence level (0.95)

Number of experimental data

Higher heating value $\left(\mathrm{J} \mathrm{g}^{-1}\right)$

Carbon content (\%) 
O Oxygen content $(\%)$

M Moisture content (\%)

A Ash content (\%)

$\mathrm{H} \quad$ Hydrogen content $(\%)$

$\mathrm{N} \quad$ Nitrogen content $(\%)$

$\mathrm{S} \quad$ Sulphur content (\%)

$\mathrm{Cl} \quad$ Chlorine content $(\%)$

\section{Subscripts}

0 Refers to initial state

$t \quad$ Refers to time $t$

ash Relates to mineral matter

$i$ Refers to experimental data at time $t$

$j \quad$ Refers to heating rate $(j=1,2,3,4)$

ad Air-dried basis

daf Dry and ash-free basis

\section{Introduction}

The continuously increasing amounts of chemicals, fuels and energy consumed have resulted in the rapid depletion of the fossil reserves that are used as raw materials in the production of these products. This is the motivation for the recent efforts toward the more effective utilization of renewable energy sources such as biomass. It is possible to produce the same products from biomass as from fossil fuels. One of the greatest advantages of renewable sources is that they do not contribute to the amount of $\mathrm{CO}_{2}$ in the atmosphere because the amount of $\mathrm{CO}_{2}$ released to the atmosphere by their combustion is compensated by the amount of $\mathrm{CO}_{2}$ consumed by plants during photosynthesis. It is therefore said that renewable sources are $\mathrm{CO}_{2}$ neutral [1]. Another advantage is that, in a time of crisis, biomass is a suitable raw material for conversion to chemicals, fuels, gases, energy or heat [2, 3]. Moreover, replacing fossil fuels with wood to produce energy would reduce the net amount of $\mathrm{CO}_{2}$ emissions to the atmosphere by over $90 \%$ [4].

One of the major methods of the production of electricity and heat from renewable sources is the co-combustion of fossil fuels (mainly coal) with biomass as a renewable energy source (RES). Global economic development has increased the acquisition and processing of wood. The result is the continuing reduction of forest resources and the formation of an increasing deficit of wood intended for industrial processing, for example, as RES.

In such case, the replacement of forestry-derived biomass with waste wood can be a very interesting solution. Additionally, to find an alternative to forest wood, a renewable energy source could, at least partially, solve the shortage problem of biomass for energy production. For this reason, in recent times, the possibility of using wood waste as fuel has been considered more and more often [5-7]. During a combustion test of wood-based panels, more than twice the enhancement of nitrogen oxide emissions level was observed compared with typical wood biomass [8].

Wood is too valuable a resource to store its wastes in landfills. The problem of wood waste management is extremely important in the European Union because of a wood raw material deficit.

In this work, furniture wood waste and its torrefied samples were investigated.

Torrefaction is a slow pyrolysis process carried out at low temperature within a temperature range of 473-600 K. Material produced in this process has a lower moisture content and higher calorific value compared with raw biomass. Furthermore, torrefaction greatly enhances the grindability of treated biomass. These biomass fuels are characterized by a higher fixed carbon and lower volatile fractions in comparison with non-thermally treated biomass [9].

In this study, thermogravimetric analysis was used to investigate the combustion characteristics of both raw and torrefied biomasses.

The temperatures of the waste from furniture wood decomposition samples and the changes in sample mass during the reactions were followed by thermogravimetric analysis (TG). The gases that evolved in the thermal oxidative degradations were studied by thermogravimetryFourier transform infrared spectrometry (TG-FTIR) [10-12]. The advantage of these methods is their simultaneity and ability to provide real-time measurements. The thermogravimetric analysis of furniture wood waste can provide information on the global effect of all the additives present in furniture wood.

It is known that the biomass is mainly composed of hemicellulose, cellulose and lignin. The variation of the constituent fractions in biomass gives different thermal behaviors and products belongs to three categories, namely, non-condensable gases, heavy volatiles (called tar) and char [1, 10, 13].

The wood characteristics and kinetics of wood combustion are essential for the modeling of the combustion in furnaces, boilers and industrial processes [4]. The kinetic parameters usually include the activation energy, the preexponential factor and the order of the reaction. The thermal analysis results show that the activation energy is the dominant factor in the reactivity equation and essentially affects the temperature sensitivity of the reaction rate. The pre-exponential factor, as well as, activation energy value is related to the material structure. However, the kinetic parameters are highly dependent on the experimental conditions (temperature, pressure and heating rate), the 
physical properties of the materials (moisture content and particle size) and the chemical composition of the solid (three main constituents and inorganic components). The effects of the above factors on the behavior of biomass decomposition under an inert atmosphere have been investigated previously, but there is insufficient information on oxidative environments. In the most recent research, biomass decomposition was studied in oxidative environments, as in works [14-17]. From the published data, it may be observed that devolatilization and char combustion lead to lower volatile yields, as well as lower reactivity of torrefied biomass char in comparison with non-treated biomass chars at high heating rates. Char combustion is slower than the pyrolysis process and impacts combustor and boiler design [17].

The oxidative process is believed to have two steps: The first step is the volatilization of the main biomass constituents and the production of char residue at low temperature; the second step includes the decomposition of lignin and the combustion of the char generated in the first stage [16]. The presence of oxygen results in the enhancement of the decomposition of the materials at low temperature and the promotion of the char residue combustion [18].

Different models are used for modeling the combustion process of biomass, especially isoconversional methods. The most popular isoconversional methods are those of Kissinger-Akahira-Sunose (KAS), Flynn-Wall-Ozawa (FWO), Coats-Redfern (CR) and Friedmann. They provide an excellent approximation of the process, but only for single-step processes. In the case of more complex processes, the activation energy values vary widely with the degree of conversion. Models based on nonlinear regression procedures ("data fitting") are the most recommended for complex chemical processes. This solution also has a drawback that knowledge of the mechanism of the process and the selection of an appropriate kinetic model are needed. This is often a problem because of the complexity of the process and the many intermediate reactions. However, in this situation, the simplest mechanism can be assumed and the appropriate kinetic model can be selected, checking the degree of fit to the experimental data. Such a method was used to investigate the combustion of the samples.

The present work concerns the study of the combustion process of raw material (waste wood from furniture) and samples torrefied at temperatures of $473,513,553$ and $593 \mathrm{~K}$.

The characterization of the products evolved during the combustion of the furniture wood waste was performed using FTIR technique. A kinetic analysis was performed, with a simple and accurate kinetic description proposed that is suitable for biomass mass loss behavior in air. A two-step reaction kinetic scheme with low- and high- temperature regions was assumed, and the values of the activation energy and pre-exponential factor for the reactions of the species were calculated and compared with values described in the literature.

\section{Experimental}

\section{Material and sample preparation}

In this research, waste wood from furniture manufacturing (FW) was used as the raw material (waste code number 030105 according to the Polish Regulation [19]). The torrefied samples (TFW) were prepared at different thermal conditions using a thermobalance TGA701 (LECO, USA) as a fixed bed reactor. First, the raw FW was dried (air-dry) and then crushed and sieved to a grain size smaller than $200 \mu \mathrm{m}$. The pretreatment FW was placed in 19 crucibles (approx. $1 \mathrm{~g}$ each) and placed in a chamber of a thermobalance. Then, the FW samples were heated (rate $20 \mathrm{~K} \mathrm{~min}^{-1}$ ) under an inert atmosphere $\left(\mathrm{N}_{2}\right)$ to the proper temperature (range 473-593 K, step $40 \mathrm{~K}$ ). When the set point temperature was reached, the samples were maintained at constant conditions for $30 \mathrm{~min}$ and then cooled down under $\mathrm{N}_{2}$ to room temperature. Subsequently, all the samples from the 19 crucibles were combined to produce one sample at the required temperature. Four torrefied samples TFW 473, TFW 513, TFW 553 and TFW 593 were obtained at four $(473,513,553,593 \mathrm{~K})$ maximum temperatures of torrefaction. Proximate and ultimate analyses were performed to determine their physicochemical properties.

\section{Methods}

\section{Proximate and ultimate analysis}

The properties of raw waste wood from furniture and its torrefied samples were determined according to laboratory procedures based on Polish standards (PN-C-04301:1987; PN-G-04516:1998; PN-G-04512:1980; PN-81/G-04513; PN-G-04534:1999).

The volatile matter content in the raw and torrefied biomass was determined by a gravimetric method. The volatile matter content was measured by weighing a closed crucible before and after heating at $850 \pm 15^{\circ} \mathrm{C}$ for $7 \mathrm{~min}$ and calculating the difference between the total mass loss and the mass loss due to water evaporation. The mass of analytical sample was $1 \mathrm{~g}$.

The ash content of the samples was determined by incineration. This method involved placing a sample in a muffle furnace and heating it in air at a specific rate up to a temperature of $600 \pm 10{ }^{\circ} \mathrm{C}$ and maintaining this 
temperature until reaching a constant mass. The mass of analytical sample was 2-3 g.

The determination of the elementary composition of $\mathrm{C}_{\mathrm{t}}^{\mathrm{a}}$, $\mathrm{H}_{\mathrm{t}}^{\mathrm{a}}, \mathrm{N}_{\mathrm{t}}^{\mathrm{a}}$ and $\mathrm{S}_{\mathrm{t}}^{\mathrm{a}}$ was executed with a vario Macro cube automatic elemental analyzer (Elementar Analysensysteme $\mathrm{GmbH}$, Germany) according to laboratory procedures. The method is based on automatic, quantitative combustion of the sample (in the analyzer tube) in a stream of oxygen at $950{ }^{\circ} \mathrm{C}$. The mass of analytical sample was approximately $0.1 \mathrm{~g}$.

The chlorine content was determined according to laboratory procedure with a bomb calorimeter. The method is based on complete combustion of the sample in a bomb calorimeter (an oxygen atmosphere) in Eschka mixture and determining the chlorine content in the solution containing the products of combustion by potentiometric titration method. The mass of analytical sample was $0.5 \mathrm{~g}$.

A higher heating value (HHV) was determined according to laboratory procedure with a LECO AC500, USA, apparatus. The method is based on complete combustion of the sample in an adiabatic system in a bomb calorimeter (an oxygen atmosphere) and measuring the increase in the water temperature in the vessel calorimeter. The mass of analytical sample was $0.5 \mathrm{~g}$.

\section{TG-FTIR analysis}

Analyses of the waste sample combustion processes were performed with coupled TG-MS-FTIR analysis techniques. A thermogravimetric analysis (TG) was carried out on an STA 409PG Luxx coupled to a quadrupole mass spectrometer QMS Aeolos (NETZSCH-Gerätebau, Germany) and Tensor 27 infrared spectrometer (FTIR) produced by Bruker Optik GmbH, Germany. The investigated sample combustion was performed at temperatures between 313 and $1273 \mathrm{~K}$ with three heating rates of 5,10 and $20 \mathrm{~K} \mathrm{~min}^{-1}$ under a flow of argon $\left(25 \mathrm{~mL} \mathrm{~min}{ }^{-1}\right)$ as a purge gas and synthetic air $\left(50 \mathrm{~mL} \mathrm{~min}^{-1}\right)$. The samples weighed $5.0 \pm 0.1 \mathrm{mg}$.

The obtained results allowed the assessment of the mass loss (TG) and the maximum rate of mass loss (DTG) during the reaction, as well as the initial and final temperatures of each stage of the combustion processes. The gaseous products were identified based on the FTIR technique.

\section{Kinetic model for the combustion of furniture waste and its torrefied samples}

A kinetic analysis was performed for the combustion of the investigated samples, which was carried out using heating rates of 5,10 and $20 \mathrm{~K} \mathrm{~min}^{-1}$. A two-step first-order model (F1F1) was assumed due to its simplicity and good fitting with experimental data.
The kinetic equations for the thermo-oxidative degradation runs can be expressed as follows:

$\frac{\mathrm{d} \alpha}{\mathrm{d} t}=k \cdot f(\alpha)$

$k=A \cdot \mathrm{e}^{-\mathrm{E}_{\mathrm{a}} / \mathrm{RT}}$

The conversion degree is defined by:

$\alpha=\frac{m_{0}-m_{\mathrm{t}}}{m_{0}-m_{\mathrm{ash}}}$

For a constant heating rate:

$\beta=\frac{\mathrm{d} T}{\mathrm{~d} t}=$ const $>0$

Equation (1) can be transformed to:

$\frac{\mathrm{d} \alpha}{\mathrm{d} T}=\frac{k}{\beta} f(\alpha)$

Integrating Eq. (5) gives:

$g(\alpha)=\int_{0}^{\alpha} \frac{\mathrm{d} \alpha}{f(\alpha)}=\frac{A}{\beta} \int_{T_{0}}^{T} \mathrm{e}^{-\mathrm{E}_{\mathrm{a}} / \mathrm{RT}} \mathrm{d} T$

Because the combustion of biomass is a very complex set of reactions, simplified kinetic models are generally applied. Biomass combustion is usually described by two main stages as follows: a devolatilization stage and a char oxidation stage. In this case, the first-order model based on consecutive reactions is correct. This model is expressed in Fig. 1.

The kinetic equation is as follows:

$\left(\frac{\mathrm{d} \alpha}{\mathrm{d} T}\right)=\frac{1}{\beta}\left[k_{1} \cdot f\left(\alpha_{1}\right)+k_{2} \cdot f\left(\alpha_{2}\right)\right]$

where

$f\left(\alpha_{1}\right)=\left(1-\alpha_{1}\right)$ and $f\left(\alpha_{2}\right)=\left(1-\alpha_{2}\right)$

represent the model of the first-order reaction $(\mathrm{F} 1)$.

In the case of TFW 593, it was assumed that the combustion process is described by one stage because first stage-devolatilization-is negligible. The kinetic equations can be expressed as follows:
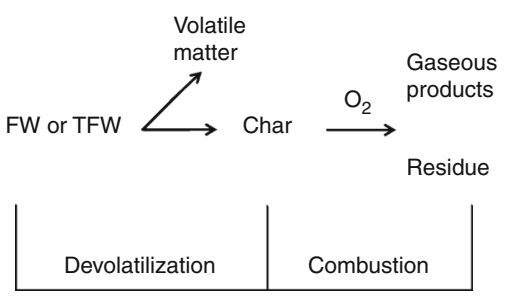

Fig. 1 Scheme of combustion process using consecutive first-order reactions 


$$
\left(\frac{\mathrm{d} \alpha}{\mathrm{d} T}\right)=\frac{1}{\beta}\left[k_{2} \cdot f\left(\alpha_{2}\right)\right]
$$

For solving Eq. (7) and Eq. (9) and calculating kinetic parameters, the numerical Levenberg-Marquardt method, which minimizes the assumed dependence, was used [20]:

$\operatorname{Min}\left[\delta\left(A, E_{\mathrm{a}}\right)\right]=\alpha-\overrightarrow{\mathrm{F}\left(A, E_{\mathrm{a}}\right)}$

where

$\mathrm{F}\left(A, E_{\mathrm{a}}\right)=\frac{\mathrm{d} \alpha}{\mathrm{d} T}$

All calculations of the kinetic parameters were performed using Netzsch Thermokinetics 3 software.

The deviation between the experimental and calculated curves is defined as:

$\mathrm{SSE}=\frac{\sqrt{\mathrm{OF} /(n-p)}}{\overline{\mathrm{TG}_{\mathrm{exp}_{\mathrm{j}}}}} \times 100 \%$

The objective function (OF) to minimize was the sum of the square difference between the experimental and calculated data [21]:

$\mathrm{OF}=\sum_{j} \sum_{i}\left(\mathrm{TG}_{\mathrm{exp}_{\mathrm{ij}}}-\mathrm{TG}_{\mathrm{calc}_{\mathrm{ij}}}\right)^{2}$

The confidence interval at a significance level $\alpha=0.05$ was estimated for kinetic parameters $\left(E_{\mathrm{a}}\right.$ and $\left.A\right)$ according to the formulas:

$$
\begin{aligned}
& \overline{E_{\mathrm{a}}}+t_{(\mathrm{n}-1 ; 1-0.5 \alpha)} \cdot \frac{S}{\sqrt{n-1}}>\overline{E_{\mathrm{a}}}>\overline{E_{\mathrm{a}}}-t_{(\mathrm{n}-1 ; 1-0.5 \alpha)} \\
& \quad \frac{S}{\sqrt{n-1}} \\
& \bar{A}+t_{(\mathrm{n}-1 ; 1-0.5 \alpha)} \cdot \frac{S}{\sqrt{n-1}}>\bar{A}>\bar{A}-t_{(\mathrm{n}-1 ; 1-0.5 \alpha)} \cdot \frac{S}{\sqrt{n-1}}
\end{aligned}
$$

\section{Results and discussion}

\section{Proximate and ultimate analyses}

Preliminary research was performed to determine the utility of wood waste from the furniture industry as an energy resource. The results of the proximate and ultimate analyses of the torrefied products are shown in Fig. 2.

As shown in Fig. 2, the physical and chemical properties of torrefied FW strongly depend on the torrefaction temperature. The same trends were observed by other researchers [22-24]. Torrefied waste from furniture (TFW), in comparison with non-thermally treated FW, contains lower amounts of moisture, volatile matter, oxygen and nitrogen. It was found that with increasing torrefaction temperature, the moisture, volatile matter and oxygen content decreased. The reduction in the volatile matter of the product of torrefaction at $573 \mathrm{~K}$ was almost doubled, decreasing from $79.5 \%$ (FW) to $43.4 \%$ (TFW 593). From Fig. 2, it can be inferred that the mass percentage of $\mathrm{C}$ in the products increased with the increase in the torrefaction temperature. In contrast, the mass percentages of $\mathrm{N}, \mathrm{H}$ and $\mathrm{O}$ showed a decreasing trend. The decreases in the hydrogen and oxygen contents were due to the dehydration and decarbonization of the biomass during torrefaction [25]. As noted (Fig. 2), the higher heating value also increased with the increasing temperature. It is clear that the emissions of $\mathrm{CO}_{2}, \mathrm{CO}$ or $\mathrm{H}_{2} \mathrm{O}$ result in a decrease in the $\mathrm{H}$ and $\mathrm{O}$ contents in furniture wood waste. The increase in the carbon content is only an apparent increase due to the decrease in the oxygen content. These results indicate that the torrefaction method most likely increases the energy density of the waste wood by removing oxygen [26-28]. The $\mathrm{O} / \mathrm{C}$ ratio decreased during torrefaction; this corresponds mainly to the loss of moisture and low-energy volatile components, which consequently increases carbon densification. This causes the torrefied biomass to resemble peat in terms of maturity. From Fig. 2, it can be inferred that the sulfur and chlorine contents did not vary much with the torrefaction temperature. The increase in the sulfur content is relative, due to the decreased level of oxygen [17]. The interesting situation can be observed in the case of nitrogen content, which firstly decreases up to $553 \mathrm{~K}$ and then increases. This is associated with a significant decrease in the volatiles matter and oxygen content (at $593 \mathrm{~K}$ almost twice), while the nitrogen content at all temperatures is similar. Accordingly, the nitrogen content can relatively increase.

In the literature, authors described different behaviors of nitrogen evolution during thermal conversion of biomass. But, there is not a lot of literature describing this phenomenon.

For example, Pelaez-Samaniego et al. [29] observed firstly approximately the same content of nitrogen (slight decrease) in torrefied bark at temperature $175-275^{\circ} \mathrm{C}$ and then observed increase at higher temperatures during the torrefaction of bark.

Other authors [30] observed different behaviors of nitrogen during torrefaction of food waste. Firstly, the nitrogen content was increased and then at $400{ }^{\circ} \mathrm{C}$ decreased. This increase is a relative increase due to the decreased level of oxygen.

\section{TG analysis}

TG and DTG curves of the combustion of the investigated samples (furniture wood waste and its torrefied samples) at a heating rate of $10 \mathrm{~K} \mathrm{~min}^{-1}$ are presented in Fig. 3 . 

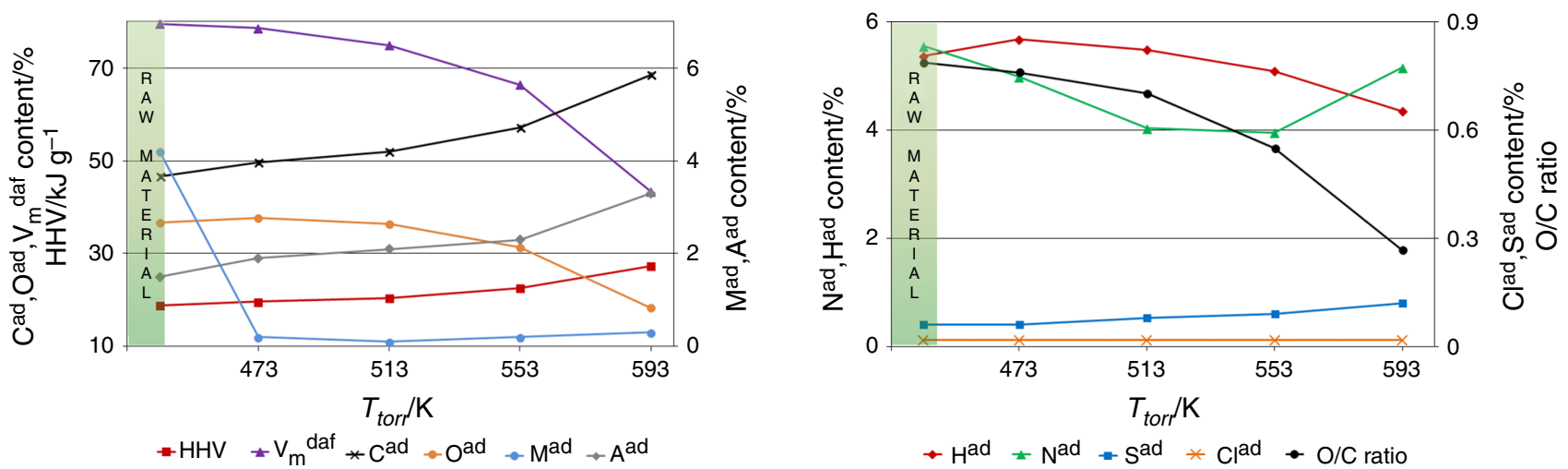

\begin{tabular}{|c|c|c|c|c|c|c|c|c|c|c|}
\hline \multicolumn{7}{|c|}{ Proximate analysis } & \multicolumn{4}{|c|}{ Ultimate analysis } \\
\hline & $\mathrm{HHV} / \mathrm{kJ} \mathrm{g}^{-1}$ & $v_{m}{ }^{\text {daf } / \%}$ & $\mathrm{C}^{\mathrm{ad} / \%}$ & $\mathrm{O}^{\mathrm{ad} / \%}$ & $\mathrm{M}^{\mathrm{ad} / \%}$ & $A^{a d / \%}$ & $\mathrm{H}^{\mathrm{ad} / \%}$ & $\mathrm{~N}^{\mathrm{ad} / \%}$ & $\mathrm{~S}^{\mathrm{ad} / \%}$ & $\mathrm{Cl}^{\mathrm{ad} / \%}$ \\
\hline $\begin{array}{l}\text { Measurement } \\
\text { uncertainty }\end{array}$ & \pm 0.2 & \pm 0.3 & \pm 0.5 & \pm 0.3 & \pm 0.1 & \pm 0.2 & \pm 0.2 & \pm 0.1 & \pm 0.03 & \pm 0.07 \\
\hline
\end{tabular}

Fig. 2 Impact of torrefaction temperature on TFW properties: proximate analysis (left site), ultimate analysis (right site) and its measurement uncertainties

The basic parameters from the TG-DTG analysis such as the temperature range of each combustion stage, the mass losses and the temperature of the maximum DTG are presented in Table 1 .

The air atmosphere seems to be a more complex condition due to the presence of oxygen, compared with the conditions of nitrogen or argon. Oxygen enhances the decomposition of the material at low temperatures, and after reaching a high enough value, it is likely to promote the combustion of the char residue generated in the early stages of the solid decomposition.

The changes in the conversion and decomposition rates during the combustion of the investigated samples are presented in Table 1 and Fig. 3. The moisture and adsorbed water content released at up to $400 \mathrm{~K}$ were excluded. The mass loss does not exceed $1.0 \%$. The decomposition region (devolatilization) is within the range of approximately $400-665 \mathrm{~K}$. This step is related to the devolatilization and oxidation of the resulting volatile components and the formation of ash. The mass losses ranged from 64.9 to $33.0 \%$ in the case of the furniture wood waste torrefied at $593 \mathrm{~K}$. Most of the hemicellulose and cellulose in the samples are decomposed, usually reaching two maxima. Lignin is decomposed above $453 \mathrm{~K}$ over a wide range of temperature with a very low decomposition rate $[10,31,32]$. However, in the case of complex samples such as biomass, the maxima of the components overlap. The cellulosic and hemicellulosic fractions are part of the holocellulose component. This is a valid approximation because the peak in DTG combustion (basically related to holocellulose devolatilization) is a symmetric peak that presents a very small hemicellulosic shoulder [33-35]. Therefore, it can be seen that for sample TFW 553, the peak is smaller than the others and that in the case of sample TFW 593, there is no peak observed. The decomposition of lignin is related to the slow process of
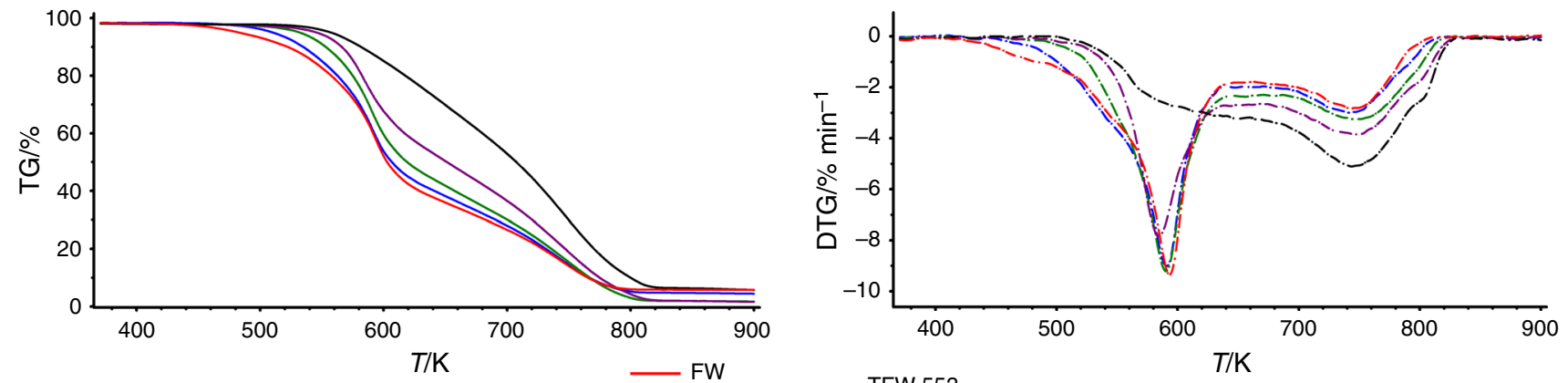

— TFW 473

二 TFW 553

Fig. 3 TG-DTG curves of the combustion of furniture wood waste and of its torrefied samples $\left(10 \mathrm{~K} \mathrm{~min}^{-1}\right)$ 
Table 1 Characteristic parameters from the TG-DTG analysis

\begin{tabular}{|c|c|c|c|c|}
\hline \multirow[t]{2}{*}{ Sample } & \multicolumn{3}{|c|}{ Maximum mass loss/\%/temperature/K } & \multirow[t]{2}{*}{ Residual mass $/ \%$} \\
\hline & $313-400 / \mathrm{K}$ & $400-665 / \mathrm{K}$ & $665-1273 / \mathrm{K}$ & \\
\hline FW & $0.8(354)$ & $64.9(593)$ & $26.6(743)$ & 6.9 \\
\hline TFW 473 & $0.6(342)$ & $63.1(591)$ & $30.1(742)$ & 5.4 \\
\hline TFW 513 & $1.0(345)$ & $59.7(590)$ & $37.0(746)$ & 1.5 \\
\hline TFW 553 & $0.8(346)$ & $51.8(584)$ & $44.8(746)$ & 1.8 \\
\hline TFW 593 & 0.9 (341) & 33.0 & $60.0(744)$ & 5.3 \\
\hline
\end{tabular}

carbonization of the lignin. Lignin is responsible for the formation of char as the final product of the first stage of the process. In the third stage, char oxidation takes place, producing new volatiles and solid residues. Mass losses range from $26.6 \%$ in the case of furniture wood waste up to $60.0 \%$ in the case of furniture wood waste torrefied at 593 K. On the basis of these data (Table 1; Fig. 2), it can be seen that the mass loss in the first stage decreases with the temperature of torrefaction, whereas the mass loss in the second stage increases. The decomposition of torrefied biomass is shifted to a higher temperature. This may be due to the removal of the hemicellulose in the torrefaction process. For the torrefied biomass devolatilization, the shoulder in the DTG curve is eliminated, especially for the sample subjected to high-temperature torrefaction. The peak of DTG along with the maximum mass loss is mainly contributed by the cellulose. The DTG peaks of the torrefied biomass are reduced significantly when the torrefaction temperature increases up to $593 \mathrm{~K}$ due to the depletion of the majority of the hemicellulosic and cellulosic fractions in the torrefaction process, as was also observed by the authors of other works [36-38].

In work [24], the authors investigated the combustion of willow (Salix viminalis L.) and its torrefied samples. The combustion processes of these samples run in the same way as in the case of furniture wood waste and its torrefied samples. Only the temperatures of maximal mass loss are slightly higher in the case of the furniture samples.

Several combustion characteristic parameters are defined as follows: the ignition temperature $\left(T_{\mathrm{i}}\right)$, the peak temperature $\left(T_{\max }\right)$, the burnout temperature $\left(T_{\mathrm{b}}\right)$ and the burning time (BT). The ignition temperature is the temperature at which a sudden decrease is noticeable in the DTG curve. The peak temperature represents the place where the rate of mass loss is at a maximum due to rapid volatilization accompanied by the formation of carbonaceous residue. The burnout temperature is the temperature on the DTG curve where the oxidation is completed. The burning time is the time interval in which the dried fuel starts to lose mass until the end of combustion, when the mass stabilizes. These parameters give a comparatively comprehensive evaluation and can be regarded as a reference for practical operation [39]. The characteristic parameters are reported in Table 2.

The ignition temperatures in the case of furniture wood waste and torrefied samples TFW 473, TFW 513 and TFW 553 are within the range from 549 to $559 \mathrm{~K}$, whereas that for sample TFW 593 is significantly higher $(600 \mathrm{~K})$. All the samples are completely burnt at the temperature of 813-843 K, after 29-35 min, depending on the torrefaction temperature. Samples with higher torrefaction temperatures have a higher ignition temperature and a shorter time of combustion. These results are in accordance with previous research [24]. The performance parameters of the combustion of willow and its torrefied samples have lower values than our samples, except for the ignition temperature. For raw samples and samples torrefied up to $513 \mathrm{~K}$, the ignition temperature is comparable, but above $513 \mathrm{~K}$, the temperature values are definitely higher in the case of torrefied willow samples. The values of the characteristic combustion parameters for exemplary biomass samples are listed in Table 3.

The ignition temperature depends on the early release of volatiles and on how quickly the heat is released by the combustion of the volatiles [43]. Thus, increasing the torrefaction temperature increases the ignition temperature because the percentage of volatiles decreases (Table 2). The ignition temperatures for the combustion of various biomass samples (Table 3) are within the range of $502 \mathrm{~K}$

Table 2 Characteristic parameters of the combustion process

\begin{tabular}{lllll}
\hline Sample & $T_{\mathrm{i}} / \mathrm{K}$ & $T_{\max } / \mathrm{K}$ & $T_{\mathrm{b}} / \mathrm{K}$ & BT/min \\
\hline FW & 549 & 593 & 813 & 35 \\
TFW 473 & 549 & 591 & 825 & 32 \\
TFW 513 & 557 & 590 & 837 & 31 \\
TFW 553 & 559 & 584 & 843 & 30 \\
TFW 593 & 600 & 744 & 843 & 29 \\
\hline
\end{tabular}


Table 3 Characteristic parameters of the combustion process for different biomass samples

\begin{tabular}{llrl}
\hline Sample & $T_{\mathrm{i}} / \mathrm{K}$ & $T_{\mathrm{b}} / \mathrm{K}$ & Reference \\
\hline FW & 549 & 813 & This research \\
Willow & 547 & 825 & {$[24]$} \\
Cornstalk & 534 & 808 & {$[40]$} \\
Rice straw & 530 & 837 & \\
Sawdust & 566 & 851 & \\
Cotton & 525 & 833 & {$[41]$} \\
Olive kernel & 519 & 813 & \\
Peach kernel & 524 & 848 & \\
Sewage sludge & 502 & 1005 & \\
Peanut shell & 544 & 890 & {$[42]$} \\
Wheat straw & 546 & 884 & \\
Rice husk & 546 & 857 & \\
\hline
\end{tabular}

for sewage sludge to $566 \mathrm{~K}$ for sawdust. The earlier ignition of sewage sludge relative to any other fuel can be explained by the fact that this material contains more easily decomposed components and has the highest $\mathrm{H} / \mathrm{C}$ ratio [41].

The ignition temperature for the investigated sample of FW is quite high compared with the other samples but is similar to the temperatures obtained for the willow, peanut shell, wheat straw and rice husk samples.

With respect to the combustion parameters, such as the burnout temperature, it can be concluded that the combustion of cornstalk, FW and olive kernel take place at the lowest temperatures of 808 and $813 \mathrm{~K}$. They are the most reactive fuels of all the samples listed in Table 3. The highest burnout temperature is observed in the case of sewage sludge, which means that it is the least reactive of the described fuels.

\section{FTIR analysis}

The qualitative analysis of the gases released during the combustion process was carried out using IR analysis. The presented spectra have the form of $3 \mathrm{D}$ graphs to show the changes during the processes. Figure 4 shows exemplary spectra recorded during the sample combustion $\left(10 \mathrm{~K} \mathrm{~min}^{-1}\right)$ for five investigated samples as follows: raw furniture waste $(\mathrm{FW})$ and torrefied furniture waste at the following different temperatures: TFW 473, TFW 513, TFW 553 and TFW 593.

Based on the presented results, the spectra recorded at the maximum gas releases were extracted. Figure 5 presents a comparison of the maximal spectra reported for each investigated sample and Table 4 are presented wave numbers of all visible key vibrations.
On the basis of the presented 3D graphs, it can be concluded that for raw furniture waste and for waste torrefied up to a temperature of $553 \mathrm{~K}$, two sharp maxima can be marked-at 598 and $750 \mathrm{~K}$. As can be observed, the main peaks at $750 \mathrm{~K}$ can be assigned to $\mathrm{CO}_{2}$ and $\mathrm{CO}$. At the lower temperature $(598 \mathrm{~K})$, water is visible, and a peak related to compounds with a $\mathrm{C}=\mathrm{O}$ band is observable. One of the hazardous substances produced in furniture waste combustion is isocyanate [44]. Figure 6 presents the spectra extracted from 3D charts and recorded at a temperature of approximately $533 \mathrm{~K}$. As seen, the peaks assigned to isocyanate $\left(2250\right.$ and $\left.2285 \mathrm{~cm}^{-1}\right)$ are noticeable [45]. However, the peak area depends on the torrefied temperature - the peaks are sharp for the raw material and waste torrefied at $473 \mathrm{~K}$, but disappear at higher torrefaction temperatures.

As can be concluded from Fig. 5, furniture waste torrefaction at a temperature over $553 \mathrm{~K}$ overcomes the isocyanate emissions during combustion.

For each sample, at three heating rates $(20,10$ and $5 \mathrm{~K} \mathrm{~min}^{-1}$ ), the evolution of the $\mathrm{CO}_{2}$ and $\mathrm{CO}$ during the combustion was calculated. The areas under the curves were integrated, normalized (particular peak area/area of all peaks) and presented in Fig. 7 as functions of the torrefaction temperature and combustion heating rate.

As can be concluded, the furniture waste torrefaction temperature has the most significant impact on the amount of released $\mathrm{CO}$ and $\mathrm{CO}_{2}$. In the case of $\mathrm{CO}_{2}$ emissions during combustion, the heating rate is another influencing process parameter. During combustion carried out at a heating rate of $5 \mathrm{~K} \mathrm{~min}^{-1}$, a greater amount of greenhouse gas is evolved than in the case of the process conducted with a heating rate $20 \mathrm{~K} \mathrm{~min}^{-1}$. The opposite situation is observed for carbon monoxide emissions. In the combustion process carried out with a heating rate of $20 \mathrm{~K} \mathrm{~min}^{-1}$, $\mathrm{CO}$ emissions are higher than in the process heated at $5 \mathrm{~K} \mathrm{~min}^{-1}$.

The temperatures of the maximal gas evolving for $\mathrm{CO}$ and $\mathrm{CO}_{2}$ in the case of torrefied samples TFW 473, TFW 513, TFW 553 and TFW 593 were determined. As can be appreciated, the temperature of gas emission depends only on the process heating rate, and in the case of faster processes $\left(20\right.$ and $\left.10 \mathrm{~K} \mathrm{~min}^{-1}\right)$, the temperatures of the maximal $\mathrm{CO}_{2}$ and $\mathrm{CO}$ emissions are similar. At $5 \mathrm{~K} \mathrm{~min}^{-1}$, the temperature of the maximum $\mathrm{CO}$ emission is lower than that of the maximum $\mathrm{CO}_{2}$ emission.

\section{Kinetic analysis of furniture wood waste and its torrefied samples}

For the combustion of the investigated biomass samples (FW, TFW 473, TFW 513 and TFW 553), a two-stage reaction kinetic model is proposed, and each reaction is 

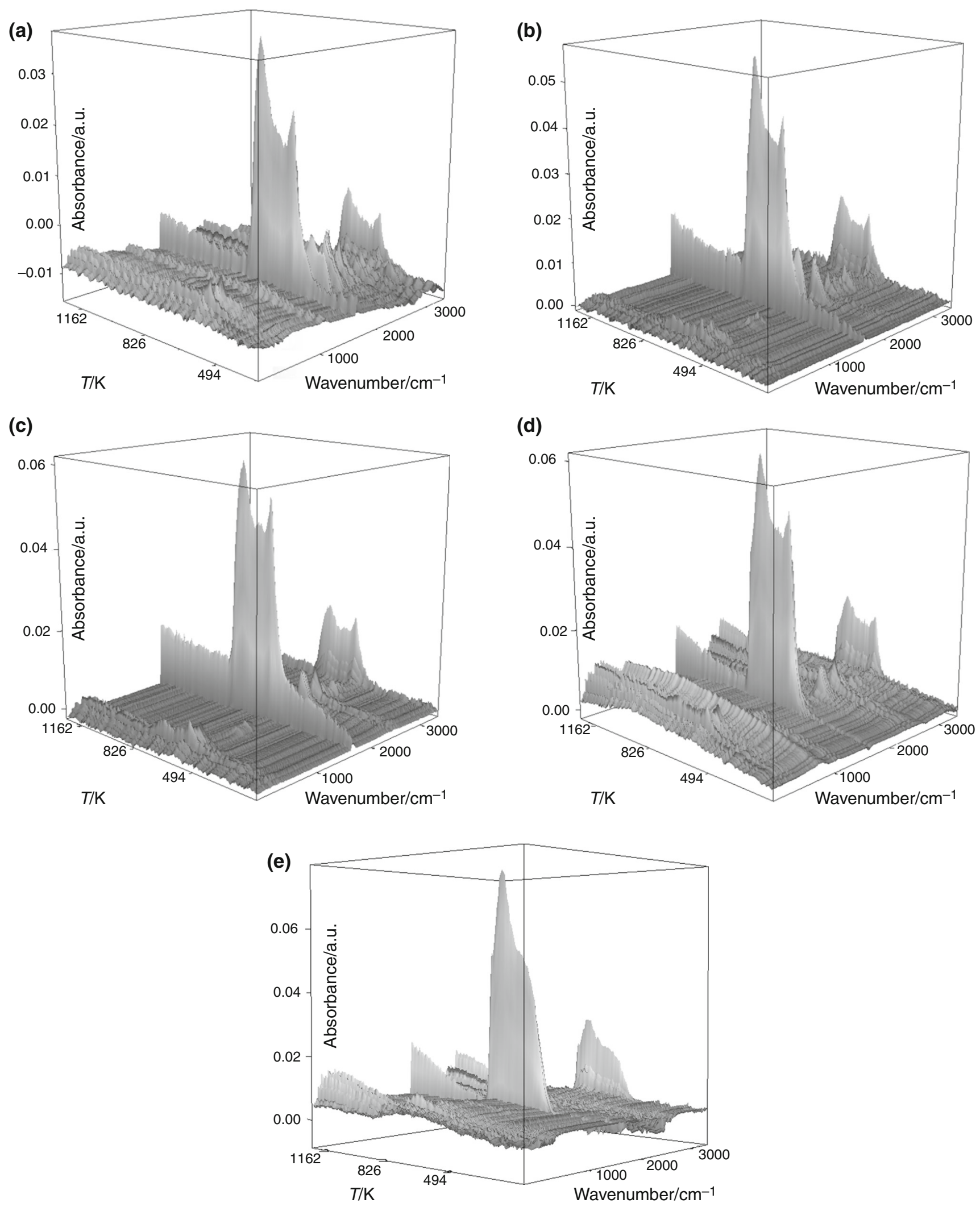

Fig. 4 3D spectra of gases released during furniture waste combustion: a FW, b TFW 473, c TFW 513, d TFW 553 and e TFW 593 
(a)

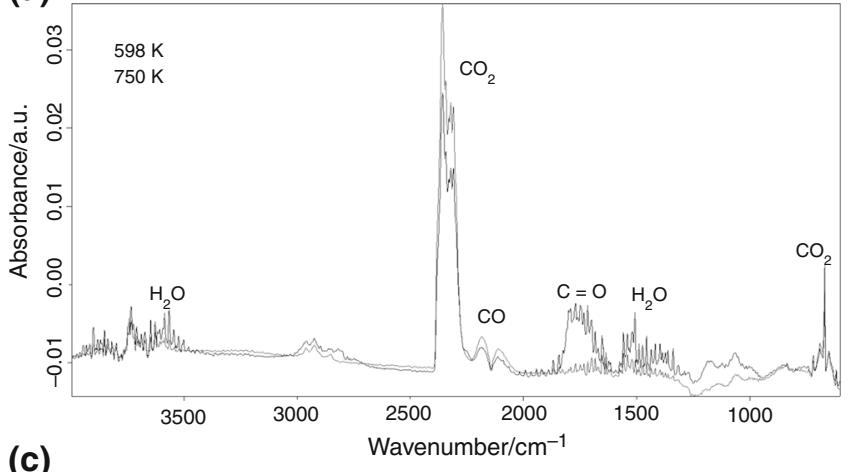

(c)

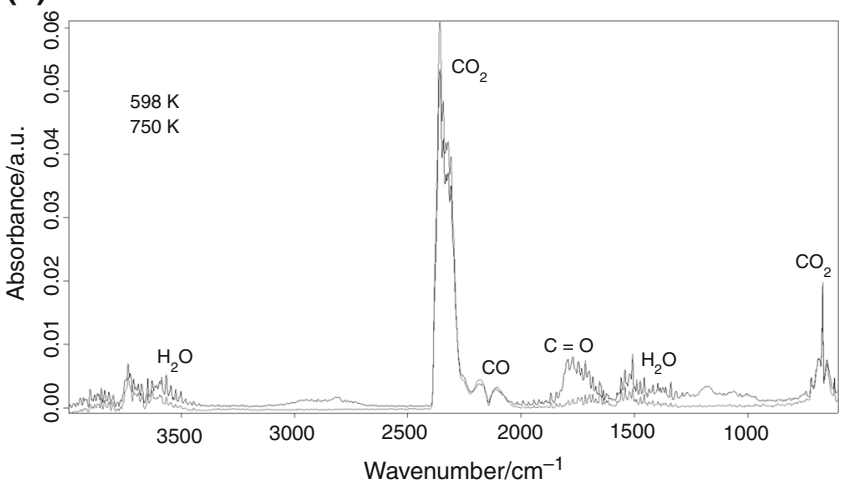

(b)

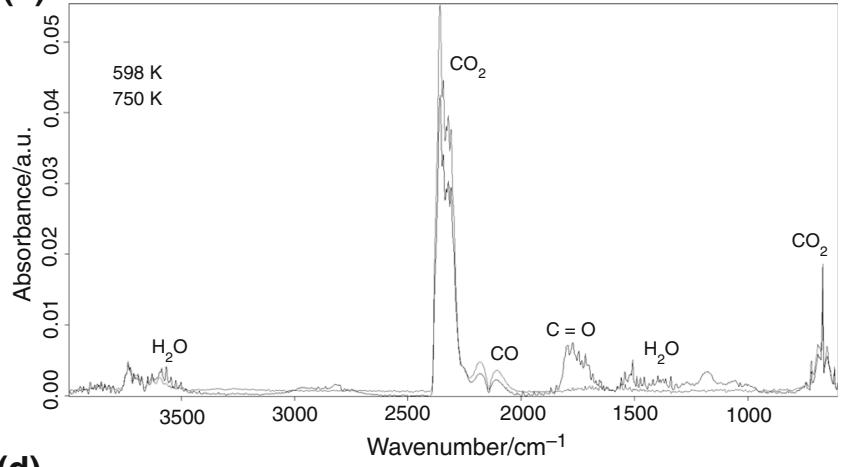

(d)

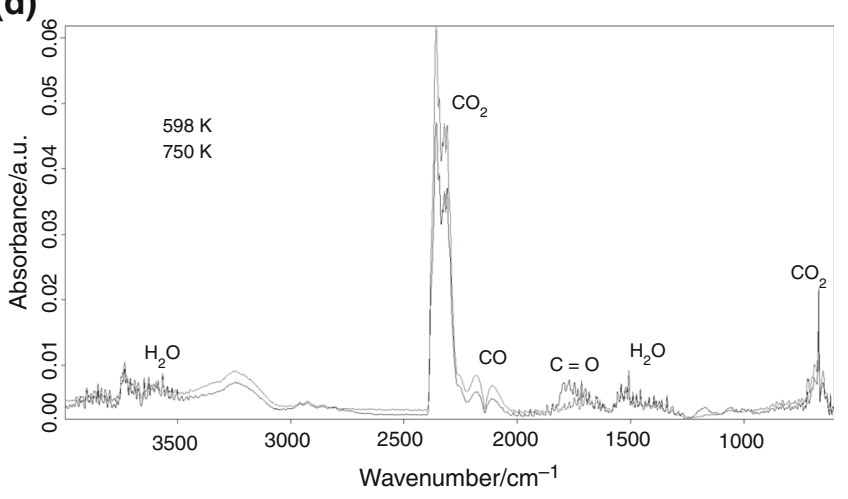

(e)

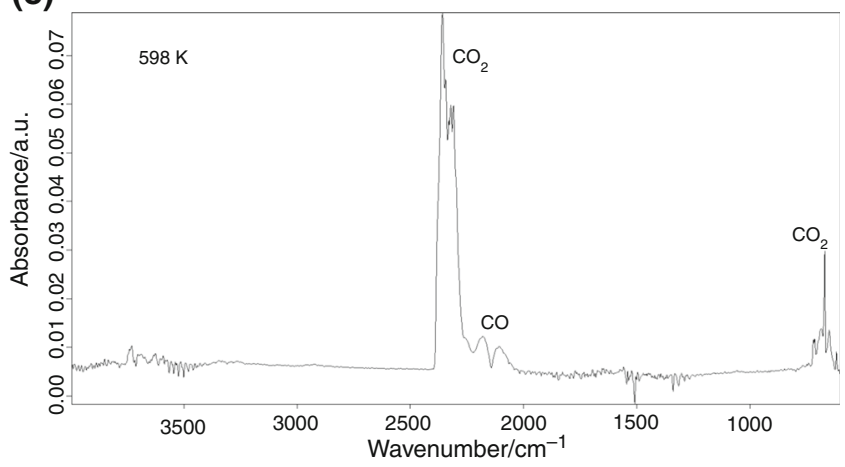

Fig. 5 Comparison of maximal spectra reported for the investigated samples: a FW, b TFW 473, c TFW 513, d TFW 553 and e TFW 593

Table 4 Wave numbers of all visible key vibrations

\begin{tabular}{ll}
$\begin{array}{l}\text { Wave numbers/ } \\
\mathrm{cm}^{-1}\end{array}$ & Compounds \\
\hline 669 & $\begin{array}{l}\text { Carbon dioxide } \\
\text { C }=\text { O in organic compounds (aldehydes and } \\
\text { acids) }\end{array}$ \\
1508 & Water \\
2114,2177 & Carbon monoxide \\
2250,2285 & $\begin{array}{l}\text { Isocyanate } \\
2300,2345\end{array}$ \\
3566 & Carbon dioxide \\
3742 & Water \\
\hline
\end{tabular}

also governed by a first-order Arrhenius law. In the case of the sample torrefied at $593 \mathrm{~K}$, a one-stage first-order kinetic model was assumed. The first region-moisture evolution-was excluded from the calculation of the kinetic parameters. The results of the calculated kinetic parameters are presented in Table 5.

Figure 8 shows the fit of the model data to the experimental data using a two-step first-order model.

The activation energy values for the first stage (devolatilization) increase with the increasing temperature of torrefaction from 68 to $125 \mathrm{~kJ} \mathrm{~mol}^{-1}$, whereas those for the second stage decrease from 108 to $47 \mathrm{~kJ} \mathrm{~mol}^{-1}$. The increasing activation energy indicates that this step is more 


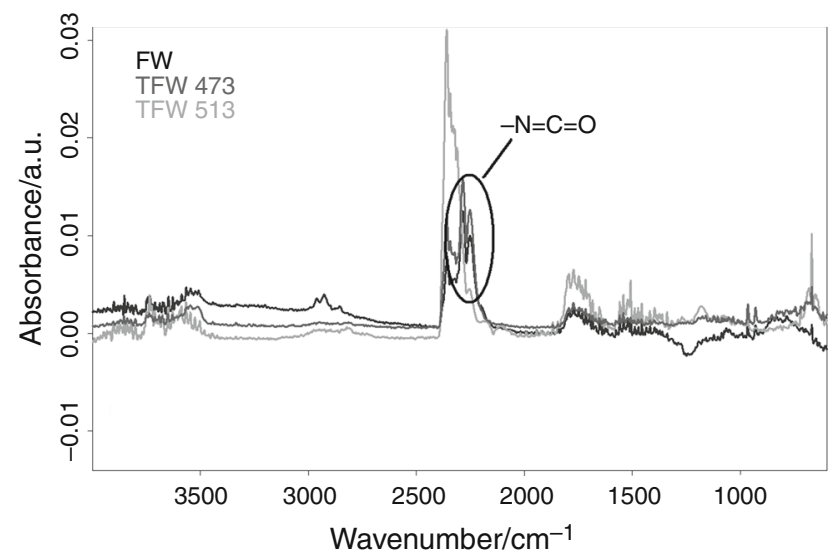

Fig. 6 Comparison of the spectra recorded at temperatures of approximately $533 \mathrm{~K}$ for FW, TFW 473 and TFW 513

resistant and slower. A similar correlation can be observed in the case of the pre-exponential value $A$. In the case of TFW 593, the devolatilization stage is negligible (many components decompose during torrefaction at $593 \mathrm{~K}$ ), so the combustion process runs as a single first-order reaction. The small values of the activation energy and pre-exponential factor indicate that the rate of the combustion process is high. In a previous work [24], the kinetics of the combustion process for willow and its torrefied samples was investigated. The same kinetic model was assumed, and the conclusion of the kinetic parameters increasing with the torrefaction temperature of the first stage and decreasing in the second stage was the same. The values of the activation energy and pre-exponential factor of the combustion process were slightly higher in the case of the willow samples than the furniture wood waste samples.

The correlation coefficient values are very high $\left(R^{2}>0.9992\right)$, and the deviations between the experimental and calculated curves are less than $6.7 \%$, which proves that the calculated data were fitted to the experimental data very well, so the kinetic model was correctly founded.

Combustion kinetics is beginning to receive increasing research interest, but there are limited published experimental data available. Most attention has been paid to the advantages of torrefied biomass compared to untreated biomass, so it is difficult to verify the obtained values of the kinetic parameters. However, the comparison of the activation energy values of the combustion of various raw biomasses is possible. Table 6 presents such a summary of results.

The kinetic parameters are highly dependent on the experimental conditions (temperature, pressure and heating rate), the physical properties of the materials (moisture content and particle size), the chemical composition of the solid (three main constituents and inorganic components) and the type of assumed kinetic model. However, it can be
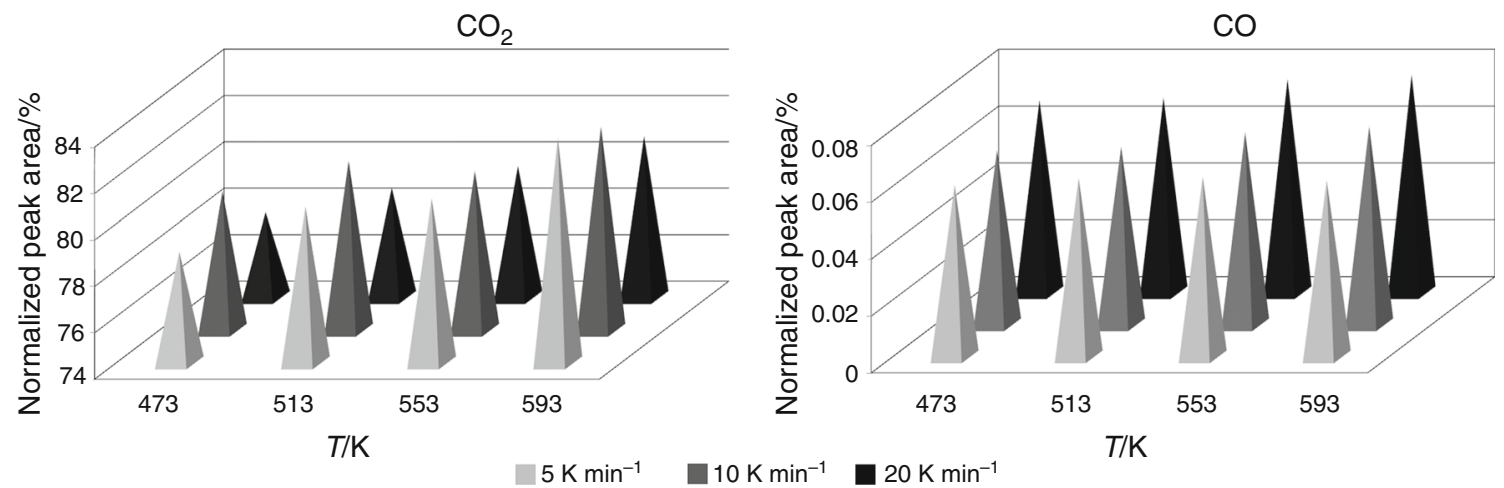

Fig. 7 Normalized area under the curve of $\mathrm{CO}_{2}$ evolution as a function of torrefaction temperature and combustion heating rate

Table 5 Kinetic parameters obtained in the thermo-oxidative degradation fitting based on consecutive first-order reactions

\begin{tabular}{|c|c|c|c|c|c|}
\hline Sample & $E_{\mathrm{a} 1} / \mathrm{kJ} \mathrm{mol}^{-1}$ & $\log A_{1}$ & $E_{\mathrm{a} 2} / \mathrm{kJ} \mathrm{mol}^{-1}$ & $\log A_{2}$ & $R^{2}$ \\
\hline FW & $68 \pm 4$ & $5.5 \pm 0.2$ & $108 \pm 5$ & $7.1 \pm 0.7$ & 0.9995 \\
\hline TFW 473 & $81 \pm 6$ & $6.7 \pm 0.5$ & $83 \pm 3$ & $5.3 \pm 0.5$ & 0.9998 \\
\hline TFW 513 & $108 \pm 3$ & $9.2 \pm 0.5$ & $70 \pm 2$ & $4.2 \pm 0.5$ & 0.9998 \\
\hline TFW 553 & $125 \pm 3$ & $10.7 \pm 0.2$ & $65 \pm 4$ & $3.8 \pm 0.2$ & 0.9999 \\
\hline TFW 593 & - & - & $47 \pm 5$ & $2.5 \pm 0.3$ & 0.9992 \\
\hline
\end{tabular}


FW

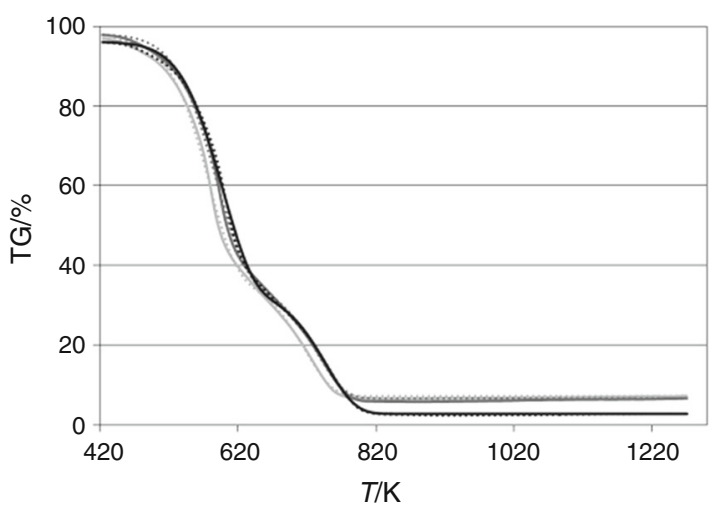

TFW 513

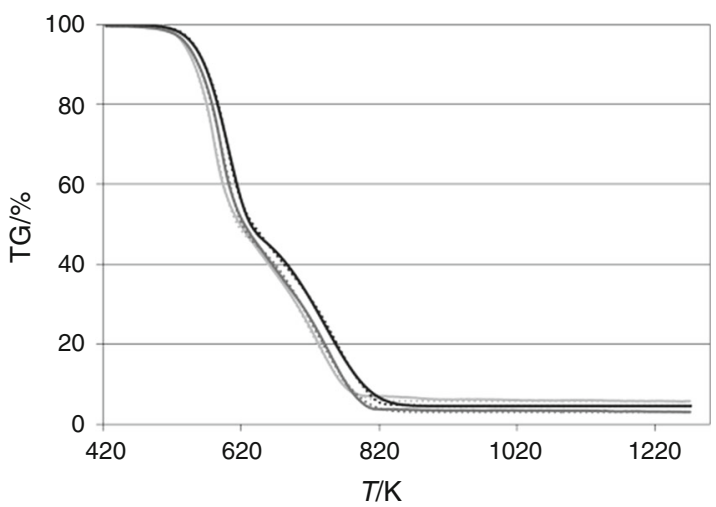

TFW 473

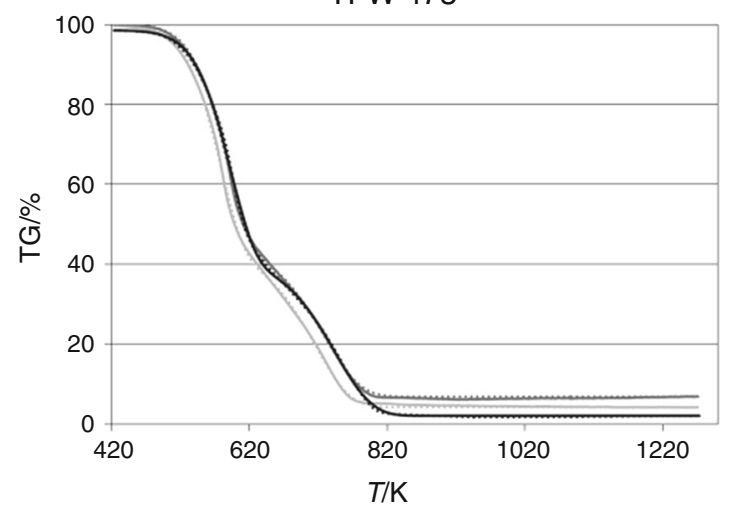

TFW 553

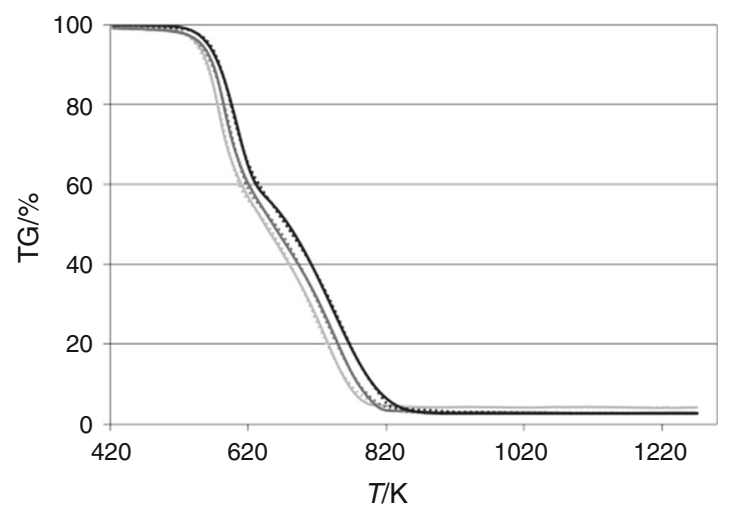

TFW 593

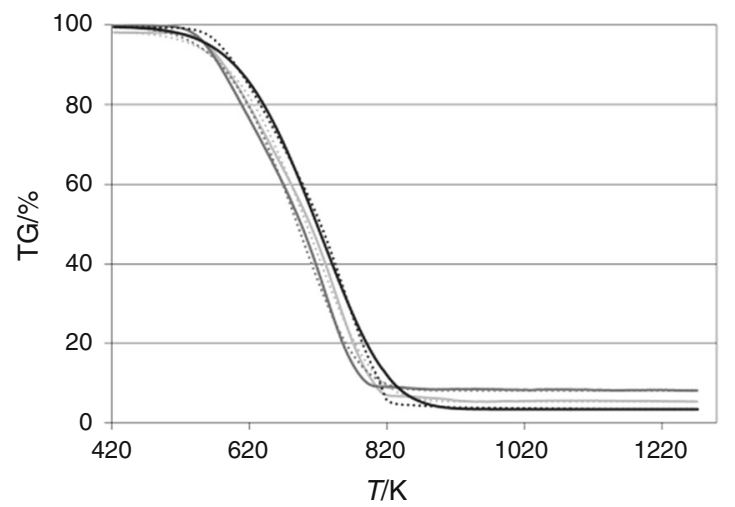

\begin{tabular}{|llr|}
\hline & Experimental data & $5 \mathrm{~K} \mathrm{~min}^{-1}$ \\
$\cdots \ldots . . . . .$. & Model & $10 \mathrm{~K} \mathrm{~min}^{-1}$ \\
& & $20 \mathrm{~K} \mathrm{~min}^{-1}$ \\
\hline
\end{tabular}

Fig. 8 Fit of TG measurements, simulated with a two-step first-order reaction model

seen that in the case of willow, cornstalk, rice straw, sawdust and different types of wood (except olive wood), the first stage has lower values of activation energy (below $100 \mathrm{~kJ} \mathrm{~mol}^{-1}$ ) than the second stage of the combustion process (above $100 \mathrm{~kJ} \mathrm{~mol}^{-1}$ ). The same trend is observed in work [48], where the authors tested four types of wood as follows: aspen, birch, oak and pine. They obtained values of activation energy from 115 in the case of aspen to 120 for pine in the first stage at $10 \mathrm{~K} \mathrm{~min}^{-1}$. The activation energies for the second-stage reaction among the species were more varied as follows: 145 for oak and pine and 210 for birch and aspen. The values of the calculated energy for 
these biomass samples are also comparable. In the case of the other biomass samples, the combustion process has very high (for seaweed and straw) or low (for olive tree and vine pruning, olive wood) activation energy values. The reason for this situation may be the structure of the biomass samples and the type of kinetic model used.

Based on the obtained kinetic parameters, the relation between them was examined for the two stages of the combustion process to provide further insight into the mechanism of oxidation of the various samples. Figure 9 presents the obtained results.

It can be seen that $\log A$ indeed varies in a linear proportion with $E_{\mathrm{a}}$, exhibiting the so-called kinetic compensation effect, yielding the correlation $\log A=a E_{\mathrm{a}}+b$, where $a$ is the proportionality constant, and $b$ is the constant at intercept $E_{\mathrm{a}}=0$.

The equations describing the trend lines are:

$$
\begin{aligned}
& \log A=0.09 E_{\mathrm{a}}-0.71 \text { in the range of temperature } \\
& 400-665 \mathrm{~K} \text { and } \\
& \log A=0.08 E_{\mathrm{a}}-1.13 \text { in the range of } 665-1273 \mathrm{~K} .
\end{aligned}
$$

In both cases, a linear interrelationship between two parameters is justified, with very good correlations of 0.9999 and 0.9992 .

The activation energy values increase (or decrease) with

\begin{tabular}{|c|c|c|c|c|}
\hline Sample & Range of temperature/K & $E_{\mathrm{a}} / \mathrm{kJ} \mathrm{mol}^{-1}$ & Kinetic model & Reference \\
\hline \multirow[t]{2}{*}{ FW } & $400-665$ & 68 & $\mathrm{~F} 1 \mathrm{~F} 1$ & This research \\
\hline & $665-1273$ & 108 & & \\
\hline \multirow[t]{2}{*}{ Willow (Salix viminalis L.) } & $423-637$ & 93 & $\mathrm{~F} 1 \mathrm{~F} 1$ & {$[24]$} \\
\hline & $637-1273$ & 146 & & \\
\hline \multirow[t]{4}{*}{ Cornstalk } & $403-656$ & 62.39 & Coats-Redfern & [40] \\
\hline & $656-828$ & 124.02 & & \\
\hline & $469-649$ & 48.47 & D1 & [9] \\
\hline & $719-829$ & 167.74 & $\mathrm{O} 3$ & \\
\hline \multirow[t]{2}{*}{ Olive tree pruning } & $440-650$ & 46.23 & D1 & [9] \\
\hline & $650-785$ & 48.24 & D3 & \\
\hline \multirow[t]{2}{*}{ Vine pruning } & $454-654$ & 60.89 & D1 & [9] \\
\hline & $654-774$ & 45.12 & D3 & \\
\hline \multirow[t]{2}{*}{ Rice straw } & $415-663$ & 62.20 & Coats-Redfern & [40] \\
\hline & $663-859$ & 102.06 & & \\
\hline \multirow[t]{2}{*}{ Sawdust } & $423-673$ & 75.07 & Coats-Redfern & {$[40]$} \\
\hline & $673-870$ & 108.40 & & \\
\hline \multirow[t]{3}{*}{ Seaweed (Posidonia oceanica) } & $473-523$ & 255.98 & Parallel reactions & {$[21]$} \\
\hline & $573-773$ & 211.25 & & \\
\hline & $573-773$ & 143.48 & & \\
\hline \multirow[t]{3}{*}{ Straw } & $473-523$ & 239.63 & Parallel reactions & {$[21]$} \\
\hline & $573-773$ & 162.13 & & \\
\hline & $573-773$ & 181.63 & & \\
\hline \multirow[t]{2}{*}{ Fire wood } & $493-643$ & 82 & $\mathrm{~F} 1 \mathrm{~F} 1$ & {$[46]$} \\
\hline & $643-763$ & 136 & & \\
\hline \multirow[t]{2}{*}{ Holm oak wood } & $457-653$ & 83 & $\mathrm{~F} 1 \mathrm{~F} 1$ & [46] \\
\hline & $653-849$ & 87 & & \\
\hline \multirow[t]{2}{*}{ Heath wood } & $465-633$ & 96 & $\mathrm{~F} 1 \mathrm{~F} 1$ & {$[46]$} \\
\hline & $633-773$ & 113 & & \\
\hline \multirow[t]{2}{*}{ Pine wood } & $453-632$ & 84 & $\mathrm{~F} 1 \mathrm{~F} 1$ & {$[46]$} \\
\hline & $632-773$ & 102 & & \\
\hline \multirow[t]{3}{*}{ Olive wood } & $313-453$ & 2.38 & Isoconversional KAS & {$[47]$} \\
\hline & $453-713$ & 24.25 & & \\
\hline & $713-1273$ & 81.04 & & \\
\hline
\end{tabular}
the pre-exponential factor. This behavior suggests that a

Table 6 Summary of kinetic parameters for various biomass samples found in the literature

F1F1: two-stage first-order reaction, D1: one-way transport/diffusion-limited reaction, D3: three-way transport/diffusion-limited reaction, O3: third-order reaction-chemical reaction 


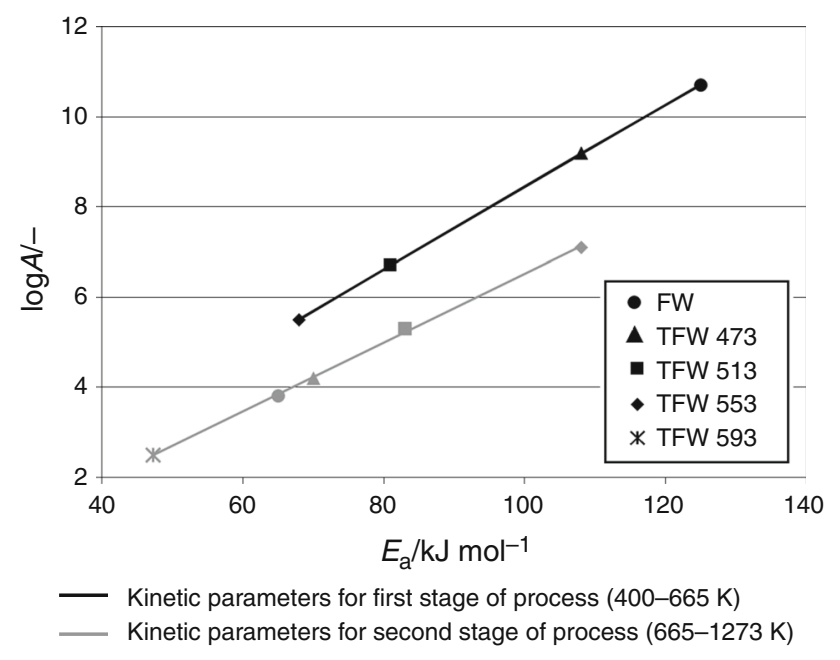

Fig. 9 Linear dependence of kinetic parameters for two ranges of temperature

compensation effect is present in the combustion of biomass, whereby a change in the activation energy is compensated by a nearly corresponding change in the preexponential factor.

\section{Conclusions}

The combustion properties of raw waste wood from furniture and samples torrefied at temperatures of 473, 513, 553 and $593 \mathrm{~K}$ were examined. A summary of the findings is as follows:

- TFW samples in comparison with FW contain a lower amount of moisture, volatile matter, oxygen and nitrogen.

- With the increasing torrefaction temperature, the moisture, volatile matter, oxygen content and $\mathrm{O} / \mathrm{C}$ ratio decreased.

- The mass percentages of the carbon and ash content in the products and the higher heating value (HHV) increased with the torrefaction temperature.

- The torrefaction process can be used to reduce the chlorinated derivative content in waste wood material.

- The mass loss in the first stage decreases with the temperature of torrefaction, whereas that in the second stage increases.

- Isocyanates are formed from incompletely torrefied furniture wood waste during heating in an oxygen atmosphere. Hence, the torrefaction of furniture wood waste at a temperature higher than $513 \mathrm{~K}$ prevents isocyanate emission during combustion.
- The torrefaction temperature has a significant impact on the emissions of $\mathrm{CO}$ and $\mathrm{CO}_{2}$ during furniture wood waste combustion.

- At a higher heating rate, more $\mathrm{CO}$ is evolved, and at a lower heating rate, more $\mathrm{CO}_{2}$ is evolved.

- The temperatures of the maximal $\mathrm{CO}$ and $\mathrm{CO}_{2}$ emissions depend only on the process heating rate; the temperature of torrefaction has no impact on the temperature of the maximal greenhouse gas emissions.

- A two-stage reaction kinetic model is proposed, and each reaction is also governed by a first-order Arrhenius law. In the case of TFW 593, the devolatilization stage is negligible, so the combustion process runs as a single first-order reaction. The proposed model fits the experimental data with very good accuracy.

- The activation energy values for the first stage (devolatilization) increase with the temperature of torrefaction from 68 to $125 \mathrm{~kJ} \mathrm{~mol}^{-1}$, whereas those for the second stage decrease from 108 to $47 \mathrm{~kJ} \mathrm{~mol}^{-1}$. A kinetic compensation effect was found for both stages.

Acknowledgements The results presented in this paper were obtained during research co-financed by the National Centre of Research and Development in the framework of Contract SP/E/1/ 67484/10 - Strategic Research Programme-Advanced technologies for energy generation: Development of a technology for highly efficient zero-emission coal-fired power units integrated with $\mathrm{CO}_{2}$ capture.

Open Access This article is distributed under the terms of the Creative Commons Attribution 4.0 International License (http://crea tivecommons.org/licenses/by/4.0/), which permits unrestricted use, distribution, and reproduction in any medium, provided you give appropriate credit to the original author(s) and the source, provide a link to the Creative Commons license, and indicate if changes were made.

\section{References}

1. Lv P, Wu C, Ma L, Yuan Z. A study on the economic efficiency of hydrogen production from biomass residues in China. Renew Energ. 2008;33:1874-9.

2. McKendry P. Energy production from biomass (part 1): overview of biomass. Bioresour Technol. 2002;83:37-46.

3. Magdziarz A, Wilk M. Thermal characteristics of the combustion process of biomass and sewage sludge. J Therm Anal Calorim. 2013;114:519-29.

4. Hagedorn MM, Bockhorn H, Krebs L, Muller U. A comparative kinetic study on the pyrolysis of three different wood species. J Anal Appl Pyrolysis. 2003;68:231-49.

5. Cichy W. Combustion of plywood waste in a low-power boiler. Drew Pr Nauk Doniesienia Komun. 2012;55(187):21-36.

6. Maryandyshev P, Chernov A, Lyubov V, Trouve G, Brillard A, Brilhac J-F. Investigation of thermal degradation of different wood-based biofuels of the northwest region of the Russian Federation. J Therm Anal Calorim. 2015;122:963-73. 
7. Sebio-Puñal T, Naya S, López-Beceiro J, Tarrío-Saavedra J, Artiaga R. Thermogravimetric analysis of wood, holocellulose, and lignin from five wood species. J Therm Anal Calorim. 2012;109(3):1163-7.

8. Wasielewski R, Hrycko P. Efekty energetyczno-emisyjne spalania odpadów z przeróbki płyt drewnopochodnych w kotle małej mocy. Archiwum Gospodarki Odpadami i Ochrony Środowiska. 2010;12(1):27-34 (In polish).

9. Toptas A, Yildirim Y, Duman G, Yanik J. Combustion behavior of different kinds of torrefied biomass and their blends with lignite. Bioresour Technol. 2015;177:328-36.

10. Liu Z, Wang S, Luo Z. Interactions of biomass components during pyrolysis: a TG-FTIR study. J Anal Appl Pyrolysis. 2011;90(2):213-8.

11. Biagini E, Barontini F, Tognotti L. Devolatilization of biomass fuels and biomass components studied by TG/FTIR technique. Ind Eng Chem Res. 2006;45:4486-93.

12. Liu Q, Wang S, Zheng Y, Luo Z, Cen K. Mechanism study of wood lignin pyrolysis by using TG-FTIR analysis. J Anal Appl Pyrolysis. 2008;82:170-7.

13. Rath J, Steiner G, Wolfinger MG, Staudinger G. Tar cracking from fast pyrolysis of large beach wood participle. J Anal Appl Pyrolysis. 2002;62:83-92.

14. Safi MJ, Mishra IM, Prasad B. Global degradation kinetics of pine needles in air. Thermochim Acta. 2004;412(1-2):155-62.

15. Branca $\mathrm{C}$, Blasi CD. Global intrinsic kinetics of wood oxidation. Fuel. 2004;83(1):81-7.

16. Fang MX, Shen DK, Li YX, Yu CJ, Luo ZY, Cen KF. Kinetic study on pyrolysis and combustion of wood under different oxygen concentrations by using TG-FTIR analysis. J Anal Appl Pyrolysis. 2006;77:22-7.

17. Ndibe C, Maier J, Scheffknecht G. Combustion, cofiring and emissions characteristics of torrefied biomass in a drop tube reactor. Biomass Bioenergy. 2015;79:105-15.

18. Bilbao R, Mastral JF, Aldea ME, Ceamanos J. Kinetic study for the thermal decomposition of cellulose and pine sawdust in an air atmosphere. J Anal Appl Pyrolysis. 1997;39:53-64.

19. Ministry of the Environment Decree of 29 December 2014 specifies the catalogue of waste with breakdown in groups, subgroups and types with indication of hazardous waste (2014).

20. Marquardt D. An algorithm for least-squares estimation of nonlinear parameters. J Soc Ind Appl Math. 1963;11(2):431-41.

21. Conesa JA, Domene A. Biomasses pyrolysis and combustion kinetics through $\mathrm{n}$-th order parallel reactions. Thermochim Acta. 2011;523(1-2):176-81.

22. Phanphanich M, Mani S. Impact of torrefaction on the grindability and fuel characteristics of forest biomass. Bioresour Technol. 2011;102:1246-53.

23. Bridgeman TG, Jones JM, Shield I, Williams PT. Torrefaction of reed canary grass, wheat straw and willow to enhance solid fuel qualities and combustion properties. Fuel. 2008;87:844-56.

24. Kopczyński M, Plis A, Zuwała J. Thermogravimetric and kinetic analysis of raw and torrefied biomass combustion. Chem Process Eng. 2015;36(2):209-23.

25. Prins MJ, Ptasinski KJ, Janssen FJ. Torrefaction of wood: part 2. Analysis of products. J Anal Appl Pyrolysis. 2006;77:35-40.

26. Poudel J, Cheon OhS. Effect of torrefaction on the properties of corn stalk to enhance solid fuel qualities. Energies. 2014;7: $5586-600$

27. Uemura Y, Omar WN, Tsutsui T, Yusup SB. Torrefaction of oil palm wastes. Fuel. 2011;90(2585-9):1.

28. Arias B, Pevida C, Fermoso J, Plaza M, Rubiera F, Pis J. Influence of torrefaction on the grindability and reactivity of woody biomass. Fuel Process Technol. 2008;89:169-75.
29. Pelaez-Samaniego MR, Yadama V, Garcia-Perez M, Lowell E, McDonald AG. Effect of temperature during wood torrefaction on the formation of lignin liquid intermediates. J Anal Appl Pyrolysis. 2014;109:222-33.

30. Poudel J, Ohmb T, Oh SC. A study on torrefaction of food waste. Fuel. 2015;2015(140):275-81.

31. Wang X, Wang K, Luo Z. Influence of the interaction of components on the pyrolysis behavior of biomass. J Anal Appl Pyrolysis. 2011;91(1):183-9.

32. Yang H, Yan R, Chen H, Lee DH, Zheng C. Characteristics of hemicellulose, cellulose and lignin pyrolysis. Fuel. 2007;86(1213):1781-8.

33. Barneto AG, Carmona JA, Ferrer JAC, Blanco MJD. Kinetic study on the thermal degradation of a biomass and its compost: composting effect on hydrogen production. Fuel. 2010;89: 462-73.

34. Kaloustian J, Pauli AM, Pastor J. Kinetic study of the thermal decompositions of biopolymers extracted from various plants. J Therm Anal Calorim. 2001;63:7-20.

35. Jauhiainen J, Conesa JA, Font R, MartÍn-Gullón I. Kinetics of the pyrolysis and combustion of olive oil solid waste. J Anal Appl Pyrolysis. 2004;72:9-15.

36. Ren S, Lei H, Wang L, Bu Q, Chen S, Wu J. Thermal behaviour and kinetic study for woody biomass torrefaction and torrefied biomass pyrolysis by TGA. Biosyst Eng. 2013;116:420-6.

37. Goldfarb JL, Liu C. Impact of blend ratio on the co-firing of a commercial torrefied biomass and coal via analysis of oxidation kinetics. Bioresour Technol. 2013;149:208-15.

38. De Caprariis B, Santarelli ML, Scarsella M, Herce C, Verdone N, De Filippis P. Kinetic analysis of biomass pyrolysis using a double distributed activation energy model. J Therm Anal Calorim. 2015;121:1403-10.

39. López-González D, Fernandez-Lopez M, Valverde JL, SanchezSilva L. Kinetic analysis and thermal characterization of the microalgae combustion process by thermal analysis coupled to mass spectrometry. Appl Energy. 2014;114:227-37.

40. Wang Q, Zhao W, Liu H, Jia $\mathrm{C}, \mathrm{Xu} \mathrm{H}$. Reactivity and kinetic analysis of biomass during combustion. Energy Procedia. 2012;17:869-75.

41. Vamvuka D, Sfakiotakis S. Combustion behaviour of biomass fuels and their blends with lignite. Thermochim Acta. 2011;526:192-9.

42. Zhang L, Duan F, Huang Y. Thermogravimetric investigation on characteristic of biomass combustion under the effect of organic calcium compounds. Bioresour Technol. 2015;175:174-81.

43. Biagini E, Tognotti L. Comparison of devolatilization/char oxidation and direct oxidation of solid fuels at low heating rate. Energy Fuels. 2006;20:986-92.

44. Tatàno F, Barbadoro L, Mangani G, Pretelli S, Tombari L, Mangani F. Furniture wood wastes: experimental property characterisation and burning tests. Waste Manage. 2009;29:2656-65.

45. Thomson M, Melling P, Slepski M. Real time monitoring of isocyanate chemistry using a fiber-optic FTIR probe. Polymer Prepr. 2001;42(1):310-1.

46. Liu NA, Fan W, Dobashi R, Huang L. Kinetic modeling of thermal decomposition of natural cellulosic materials in air atmosphere. J Anal Appl Pyrolysis. 2002;63:303-25.

47. Garcia-Maraver A, Perez-Jimenez JA, Serrano-Bernardo F, Zamorano M. Determination and comparison of combustion kinetics parameters of agricultural biomass from olive trees. Renew Energy. 2015;83:897-904.

48. Shen DK, Gu S, Luo KH, Bridgwater AV, Fang MX. Kinetic study on thermal decomposition of woods in oxidative environment. Fuel. 2009;88:1024-30. 